\title{
THE MODERATING EFFECTS OF CORPORATE SOCIAL RESPONSIBILITY ASSURANCE IN THE RELATIONSHIP BETWEEN CORPORATE SOCIAL RESPONSIBILITY DISCLOSURE AND CORPORATE PERFORMANCE
}

\begin{abstract}
The aim of this research is to analyze the impact of corporate social responsibility (CSR) disclosure on corporate performance. Likewise, it also contributes and analysis of the moderating effect of CSR assurance on the association between CSR disclosure and corporate performance. The theoretical framework of the study is based on stakeholder theory and legitimacy theory. The sample used consists of 9,861 international firm-year observations collected from the Thomson Reuters database between 2009 and 2018. Our model has been estimated using the generalized method of moments (GMM) estimator. The findings show that CSR disclosure is positively associated with corporate performance, as we had proposed in our hypothesis. Additionally, our evidence also shows that CSR assurance plays a positive moderating role between CSR disclosure and corporate performance.
\end{abstract}

Key words: CSR disclosure, corporate performance, stakeholder theory, legitimacy theory, CSR assurance

JEL code: DO2, M14, O3, 


\section{Introduction}

In recent years, there has been a considerable increase in the disclosure of corporate social responsibility (CSR) at the international level. This is due to stakeholders' growing interest in acquiring a type of information that complements the economic-financial information that firms have been required to report for years. According to Carroll and Shabana (2010), CSR practices help firms to improve their transparency with regard to social and environmental issues so that they can be legitimated by their stakeholders and by society at large. Likewise, CSR disclosure can allow firms to develop and improve their corporate image and supply useful information for stakeholders' investment decisions (Deegan \& Blomquist, 2006), especially in these times of pandemic, when CSR information acquires great relevance because of the need for information that investors and stakeholders in general currently have.

The potential value that CSR disclosure has for stakeholders is a topic that has attracted considerable attention in the world of academic research, and many studies analyze the usefulness of CSR disclosure for stakeholders. Thus, Kreitner (2001) proves that CSR disclosure can lead to client loyalty, stakeholder support and greater corporate reputation. When firms introduce CSR in their operations, they enjoy long-term benefits, such as the retention of high-quality employees, higher standards for employees, attracting socially-aware investors, greater solvency in the financial market or increased awareness of their public image. Hence, CSR disclosure is a win-win proposal, since both society and socially responsible firms can obtain long-term benefits (Kurschner, 1996), since, as noted by Cahan, De Villiers, Jeter, Naiker, and Van Staden (2016), CSR disclosure leads to economic benefits in terms of higher firm performance.

According to stakeholder theory, CSR disclosure is an important element that firms can use to manage or respond to a variety of stakeholders such as investors, consumers or suppliers, among others, to obtain their support and approval (Gray, Kouhy, \& Lavers, 1995), while also proving useful for shareholders insofar as CSR initiatives may have an impact on firm value and performance. In this regard, Nekhili, Nagati, Chtioui, and Rebolledo (2017) argue that stakeholder theory can provide a solid framework for the relationship between CSR disclosure and firm performance. This theory suggests that a firm's success depends largely on its capacity to meet stakeholders' requirements and that the information provided by CSR is an important element that firms may use to manage or answer stakeholders demands, the latter being mainly interested in risk assessment and likely expected future profitability. 
As for legitimacy theory, firms engage in CSR practices to fulfil their social contract with society (Hahn \& Lülfs, 2014). For Tilling (2004), this theory suggests that CSR may help to establish and maintain social expectations, which will lead to better economicfinancial results and increase firm value. Social expectations are based on stakeholders' implicit and explicit perceptions of how a firm should operate. According to Deegan (2006, p. 278), stakeholders' explicit expectations are focused on legal requirements, whereas social expectations that are not legislated are considered implicit. Therefore, firms seek to maintain or improve legitimacy by operating in a way that successfully addresses social standards and expectations (Hahn \& Lülfs, 2014). In other words, to acquire legitimacy, firms must do the right thing, which will lead to better corporate results. Hence, these theories provide a solid framework to explain the positive effect of CSR disclosure on firm value (Nekhili, Nagati, Chtioui, \& Rebolledo, 2017).

Many of the previous studies on the impact of CSR disclosure on firm performance focus on a specific country or geographical area. Noteworthy among them are those by Cormier and Magnan (2007) for firms based in Canada, Germany and France; Aerts, Cormier, and Magnan (2008) for a sample of firms belonging to the European Union and North America; Lindgreen, Swaen, and Johnston (2009) for North American firms; or Chen and Wang (2011) for firms in China. In view of the above, the aim of this research is to provide further evidence of the impact of CSR disclosure on firm performance by using an international sample of firms from 16 countries. Additionally, we also examine the moderating impact of CSR assurance by an external assurance provider on the association between CSR disclosure and firm performance, since the assurance of CSR disclosure can provide stakeholders with an objective, reliable and credible view of how firms are managing social and environmental risk. This research will focus on stakeholder theory and legitimacy theory. In general, our findings show that CSR disclosure has a positive effect on firm performance, also revealing that CSR assurance positively moderates the positive effect of CSR disclosure on firm performance.

Regarding the contributions of this research, we may affirm that our evidence extends the state-of-the-art on the impact of CSR disclosure on firm performance using a sample of 16 countries, thus complementing prior studies that focus on a single country or specific geographical regions, such as Canada, Germany, the United States or China. Another contribution of this research concerns how CSR disclosure may be considered a determining factor in firm performance. Specifically, it is significant that firms believe that engaging in properly managed social and environmental initiatives tends to improve their firm 
performance. Finally, another contribution stems from our findings: on the one hand, our results reveal that CSR disclosure has a positive impact on firm performance; and, on the other hand, there is evidence that the moderating effect of CSR assurance has a positive effect on the relationship between CSR disclosure and firm performance. This corroborates the results previously obtained by other researchers such as Cormier and Magnan (2007) and Clarkson, Li, Richardson, and Tsang (2019), who document the positive effect of CSR disclosure on firm performance while also proving that CSR assurance positively moderates such relationship.

Our paper is arranged as follows: the theoretical framework is described in the following section; section three formulates the research hypotheses; section four describes the sample, methodology and variables used; section five presents an analysis of the results; and, finally, section six covers our conclusions and the implications of our findings.

\section{Theoretical framework}

The initial idea established by Friedman (1970) claiming that social responsibility initiatives were created to increase firm performance and that corporate managers were only accountable to shareholders has given way to the consideration that a firm is not only accountable to such shareholders but must also address the different needs of groups of individuals that can affect or be affected by the firm (i.e., stakeholders). The reasoning behind this is that a firm's development relies on different stakeholders who supply crucial resources that are essential for corporate success (Freeman, 1984). According to Barnett and Salomon (2012), engaging in socially responsible behaviors is one of the main mechanisms whereby firms can foster and maintain trusting relationships with stakeholders. Furthermore, Jones (1995) claims that certain corporate social responsibility practices are an expression of the building of trusting and cooperative relationships between firms and stakeholders and should be positively associated with corporate performance. Thus, for example, firms whose performance is solid find it easier to attract better employees. Stakeholder theory has also been used by Donaldson and Preston (1995) to explain how firms that engage in different activities and achieve corporate performance goals also strive to meet stakeholders' expectations.

Stakeholder perspective suggests that a firm might be regarded as a set of interdependent relationships among stakeholders, who include not only shareholders but also every group or individual that may affect or be affected by the firms' activities (Clarkson, 1995). This theory also argues that a firm's success largely depends on its ability to meet stakeholders' expectations and satisfy their need for information. According to this view, CSR 
information is an important element that firms can use to manage or respond to a variety of stakeholders such as investors, consumers or suppliers, among others, to gain their support and approval (Gray, Kouhy, \& Lavers, 1995). This point of view leads Dhaliwal, Radhakrishnan, Tsang, and Yang (2012) to consider that CSR disclosure may be useful for stakeholders insofar as CSR initiatives can affect firm value and performance. Therefore, stakeholder theory provides a solid framework to understand the positive effect of CSR disclosure on firm value (Nekhili, Nagati, Chtioui, \& Rebolledo, 2017).

According to this theory, stakeholder groups, particularly shareholders, are mainly concerned with the expected future profitability of the firm. In this regard, CSR reports provide incremental information that directly affects firms' profitability (Cormier \& Magnan, 2015). Such information allows stakeholders, shareholders among them, to better assess the firms' future earnings and the potential risks associated with the expected cashflow, and may generate benefits for firms by helping them to mitigate the potential damage of negative events (Peloza, 2006).

Another theory that may be used in CSR disclosure is legitimacy theory, whereby firms engage in their CSR practices to fulfill their social contract with society (Hahn \& Lülfs, 2014). This contract is based on stakeholders' implicit and explicit perceptions of how a firm should operate (Deegan, 2006, p. 276), explicit stakeholder expectations being legal requirements whereas implicit expectations would be non-legislated social requirements. Thus, to have legitimacy, a company must satisfactorily meet social rules and expectations and do things properly (Hahn \& Lülfs, 2014). According to Tilling (2004), legitimacy theory enables CSR activities to help to establish and maintain social expectations, since it improves reputation and legitimacy, which, in turn, leads to better economic-financial results and enhances firm value.

Both legitimacy theory and stakeholder theory predict that organizations strive to obtain the approval of other actors; however, the main difference between them is that the former regards society as a whole, while stakeholder theory recognizes that, within society, certain groups are more powerful than others (Reverte, 2016). Hence, CSR disclosure could be driven by the pressure exerted by stakeholders and society, and such disclosure is likely to reduce information asymmetries and, therefore, be rewarded by investors with higher market value. Likewise, investors may use CSR disclosure to improve their estimates of the firm's value and the price they are willing to pay for its shares (Cormier \& Magnan, 2007).

\section{Research hypotheses}

\subsection{CSR disclosure and firm performance}


There are several studies at the international level that address the relationship between CSR disclosure and firm performance. However, in their analysis of Canadian firms, Richardson and Welker (2001) obtained an unexpected negative result between CSR disclosure and firm performance, while other authors report a positive relationship between both constructs. Thus, for firms based in Canada, Germany and France, Cormier and Magnan (2007) find evidence of a positive relationship between CSR disclosure and firm performance. Similarly, Aerts, Cormier, and Magnan (2008), using a sample of European Union and North American firms, also report that CSR disclosure enhances firm value.

According to Lindgreen, Swaen, and Johnston (2009), most firms in the United States believe in the positive impact of CSR disclosure on their firm performance, since companies that are perceived as having a strong social and environmental commitment usually have greater capacity to attract and maintain employees, and are also considered a form of investment that creates opportunities for future expansion and growth (Husted, 2005). In the same vein, DiSegni, Huly, and Akron (2015) found that firms that are proactive in CSR and environmental sustainability issues are characterized by significantly higher yields and profits than the industry and sector they operate in.

Other studies also advocate the positive impact of CSR disclosure on firm performance. In this regard, Andersen and Dejoy (2011), using a sample of 550 North American firms, concluded the existence of a positive relationship between the two constructs, considering the need to include appropriate control variables that may affect such relationship, such as firm size and activity sector. For businesses based in China, Chen and Wang (2011) found that firms' social responsibility activity could improve the financial results of the current year and have significant effects on their financial results in the years ahead. In Malaysia, Saleh, Zulkiflib, and Muhamad (2008) analyzed 200 firms between 2000 to 2005 based on data selected from the yearly reports of the studied firms. Their findings show that corporate social responsibility has a positive impact on the firm's performance of the matching period. Changes in firm performance in response to the corresponding corporate social responsibility increases or decreases are quite clear and statistically significant. Similarly, Choi, Kwak, and Choe (2010) used a sample of firms listed on the Korea Stock Exchange in the 2002-2008 period. Their results suggest that it is important for firms to be aware of the aspect of their social responsibility that is most relevant to their stakeholders, and also that social initiatives, when properly driven, tend to improve corporate results.

The study by Charlo and Moya (2010) focused on a sample of 87 Spanish firms belonging to different sectors with the purpose of comparing the main financial parameters of 
socially responsible firms with their counterparts that do not meet this condition to analyze the possible existence of significant differences between both groups. In addition to their systematic risk, socially responsible firms obtain higher return than those that do not fulfil such requirements. Therefore, it is reasonable to expect that these firms offer a better investment opportunity, since the profit they yield is greater than the corresponding risk.

Examining firms of several countries, Martínez-Ferrero and Frías-Aceituno (2015) analyzed the relationship between firms' sustainable behavior and their financial performance, using a sample of 1,960 non-financial firms listed on the stock exchange and belonging to 25 countries. Corporate social responsibility information was obtained from the EIRIS database. According to their findings, firms with higher levels of financial performance allocate more resources to the improvement of sustainable practices, which focus on social aspects and on the improvement of their relationship with stakeholders. This translates into better general performance brought about by the impact of corporate social responsibility on corporate reputation, which leads to enhanced firm performance.

Nekhili, Nagati, Chtioui, and Rebolledo (2017) conducted a study based on a sample of 91 French companies over a 10-year period. The data were obtained from the ThomsonOne database and the study distinguished between family and nonfamily firms. According to their results, financial performance based on market value measured using Tobin's $Q$ is positively related to CSR disclosure in family firms. This means that such firms greatly benefit from communicating their commitment to CSR. Specifically, they could obtain shareholders' endorsement more easily than nonfamily firms.

Several authors have attempted to justify the positive relationship between CSR disclosure and firm performance. Thus, Dam and Scholtens (2015) claim that CSR disclosure and firm performance are theoretically positively associated with each other. Such authors found that a firm's social responsibility might increase its market value and therefore enhance firm performance. Preston and O'Bannon (1997) mention positive synergies to establish a positive relationship and consider it consistent with stakeholder theory as applied to CSR in the literature. Patterson (2013) also refers to this positive relationship, expecting CSR disclosure to boost firms' sales growth, attract skilled employees and reduce the cost of capital. Hence, CSR disclosure would improve firm value and, thereby, firm performance. In the light of the arguments set out above, we propose the following hypothesis:

H1: There is a positive association between CSR disclosure and firm performance.

\subsection{CSR assurance as a moderating variable}


The terms assurance and audit are often used interchangeably, although the latter may be considered a form of assurance. According to the Institute of Internal Auditors (2012, p. 9) "the objective of assurance services is to examine evidence for the purpose of providing an independent assessment on governance, risk management and control processes for the organization". This definition seems to suggest that assurance consists in verifying the integrity and validity of the different types of disclosure made by firms, including sustainability reports (Soh \& Martinov-Bennie, 2015). According to Ackers (2011) and Park and Brorson (2005) CSR assurance is a process that verifies the three dimensions of CSR: social, environmental and economic, so that CSR assurance affords integrity and validity to the information included in CSR or sustainability reports, as well as providing the information disclosed with greater credibility.

Regarding the benefits that CSR assurance may provide, authors such as Perego and Kolk (2012) and Akisik and Gal (2020) consider that it can enhance the credibility of the information, minimize risk, increase corporate reputation and contribute towards better stakeholder understanding, although CSR assurance may also entail costs derived from the nature of the data contained in the reports and the assurance process. Nevertheless, certain authors (De \& Sen, 2002) claim that costs can be recovered through greater reliability, since assured reports will have a positive market signaling effect (García-Sánchez \& NogueraGámez, 2017).

On their part, Clarkson, Li, Richardson, and Tsang (2019) reveal that CSR assurance improves the quality of CSR reporting. In the same vein, Michelon, Patten, and Romi (2019) prove that external assurance of CSR disclosure may offer stakeholders, especially shareholders, a credible signal of how firms are managing social and environmental risk. Likewise, Fuhrmann, Otto, Looks, and Guenther (2017) find that assurance of CSR reports tends to reduce the asymmetries of information measured according to the supply demand relationship across Europe.

Using a sample of North American firms, Dhaliwal, Li, Tsang, and Yang, (2011) find that assured CSR reports tend to have a stronger effect on the reduction of the cost of firms' social capital, which suggests that assurance is a successful mechanism to improve credibility, reputation and market value. Casey and Grenier (2015) elaborate on the work of the previously mentioned authors and prove that capital cost reduction is significantly higher when the CSR assurance provider is an accounting firm. Likewise, based on a sample of North American firms, authors such as Peters and Tomi (2015) obtained a positive association between CSR assurance and market value. Along the same lines, the results reported by 
Clarkson, Li, Richardson, and Tsang (2019) in their study on a sample of firms from 40 countries, reveal that, although firms that engage in CSR disclosure assurance incur costs, they will also gain benefits that will enhance their market value. Based on the foregoing, we suggest the following hypothesis:

H2: The association between CSR disclosure and firm performance is moderated by CSR assurance.

\section{Empirical design}

\subsection{Sample}

We have used an initial sample of 14,003 international firm-year observations for a period from 2009 to 2018. We have excluded financial entities and those firms for which some data were unavailable. The exclusion of financial entities was because these firms prepare their annual financial statements with accounting rules different from those followed by non-financial firms. This makes it difficult to compare annual financial statements between financial and non-financial firms. Then, our final unbalanced panel data sample consisted of 9,861 international firm-year observations (The total number of firms in the sample is 1,061). All necessary data for doing this research have been collected from the Thomson Reuter database.

Our international sample comprises 16 countries around the world. Specifically, the countries represented in our sample are shown in Table 1, and are Australia, Austria, Belgium, Canada, Denmark, Finland, Germany, Ireland, Japan, Netherlands, New Zealand, Norway, Sweden, Switzerland, United Kingdom and United States. The United States, Japan and the United Kingdom are the most represented countries with $35.70 \%, 15.10 \%$ and $11.90 \%$, respectively. Regarding the lowest representation, Austria has a weight of $0.3 \%$ in the sample, New Zealand 0.5\%, Norway $0.6 \%$ and Belgium 0.9\%. By considering different countries, different institutional contexts are taken into account, which enriches the analysis and provide an international perspective on the topic.

\section{Insert Table 1}

In Table 2, we provide the percentage of firms operating in each of the nine industries used in this research. We base on the TRBC economic sector classification provided by Thomson Reuters, consistent with the Global Industry Classification Standard (GICS). The nine sectors are the following: (1) Basic Material, (2) Consumer Cyclical, (3) Consumer NonCyclical, (4) Energy, (5) Healthcare, (6) Industrial, (7) Technology, (8) Telecommunications Services and (9) Utilities. As appreciated, in the industrial sector operates $21.70 \%$ of the firms in our sample, $19.90 \%$ in the Consumer cyclical sector, in the Basic Materials sector $13.80 \%$, 
in Consumer Non-Cyclical 10.00\%, in the Healthcare, Technology and Energy sectors $8.90 \%$, $8.80 \%$ and $8.7 \%$, respectively, the Utilities sector $5.00 \%$ and, finally, Telecommunications Services $3.30 \%$.

Insert Table 2

\subsection{Measurements}

\subsubsection{Dependent variable}

Firm performance, our dependent variable, can be proxied by using accounting-based (e.g, Return on assets) or market-based measures (e.g., Tobin's q). Accounting indicators have received many criticisms because they are more subjective than market metrics as well as more susceptible of being manipulated by management and owners, for instance, by means of depreciation and amortization. Thus, in line with these arguments, we measure firm performance by employing a market metric. Specifically, we use the Tobin's q for calculating our dependent variable, labeled as Q_TOBIN, and measured as the market capitalization of common stock+ book value liabilities divided by the book value of total assets consistent with preceding research (e.g., Boakye, Tingbani, Ahinful, \& Nsor-Ambala 2021; García-Ramos, Díaz-Díaz, \& García-Olalla et al. 2017; Lin, Ho, \& Lee, 2020).

\subsubsection{Independent variables}

As independent variable, we use CSR reporting, denoted by CSR_REPORT, and is calculated as the ratio between the aggregation of 123 items concerning social and environmental issues and the total items (123). Every one of these items is shown in Table 3 and it will be measured as a dummy variable that will take the value 1 if firms disclose this item and 0 , otherwise. Therefore, our independent variable will go from 0 to 1 . Hence, a company with 0 points has no reporting of CSR information, a company with $0.1-0.5$ points has moderate reporting of CSR information, a company with 0.6-0.9 points has a relevant reporting of CSR information and a company with 1 point has complete reporting of CSR information. The construction of our CSR reporting index is in line with other researchers such as Siueia, Wang, and Deladem (2019), among others.

\section{Insert Table 3}

Furthermore, our moderating variable, CSR repots assured by an external assurance provider, denoted as CSR_SUST_EXT_AUD, is calculated as a dummy variable, coded 1 if the firm's CSR report is assured by an external auditor (external assurance provider) and 0 , otherwise. In order to explore the moderating effect of having CSR reports assured by 
external assurance providers between CSR disclosure and firm performance, we have constructed the interaction CSR_REPORT x CSR_SUST_EXT_AUD.

\subsubsection{Control variables}

Factors potentially affecting firm performance are also controlled (Pucheta-Martínez \& Gallego-Álvarez, 2020). The first control variable considered is firm size, SIZE, measured as the $\log$ of total assets. A positive association is expected between firm size and firm performance. Leverage is another control variable included in the model. This variable is labeled as LEV and is measured as the ration between total debt and total assets. More leverage in firms may result in worse firm performance. CEO duality is also controlled as a factor influencing firm performance. This variable is measured as a dummy variable that takes the value 1 if the same person serves simultaneously as chief executive officer (CEO) and President of the board and 0, otherwise. Firms will perform poorer when the CEO of the firm serves simultaneously as president of the board. Outsiders is another factor considered in this research. This variable is denoted by OUTSIDERS and is measured as the ratio between the total number of external directors on boards and the total number of directors on board. It is predicted a positive association between outsiders and firm performance. Board size is another control variable included in the model. This variable is labeled as B_SIZE and is calculated as the total number of board size. We expect that bigger boards will perform better. The industry in which each firm operates is also considered. This variable will be coded as 1 if the firm operates in the industry analysed and 0 , otherwise. We denote this variable as INDUSTRY and we consider nine sectors: basic materials, consumer cyclical, consumer noncyclical, energy, healthcare, industrials, technology, telecommunication services and utilities. Lastly, year effects have been also controlled by including a set of dummies variable. We label this variable as YEAR. A summary of all the variables used in this research are provided in Table 4.

\section{Insert Table 4}

\subsection{Economic model}

By estimating the following model, the hypotheses will be checked:

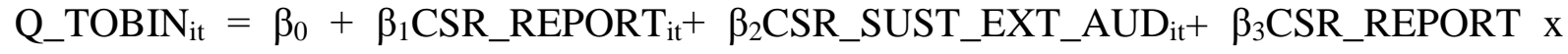

$$
\begin{aligned}
& \text { CSR_SUST_EXT_AUD }{ }_{i t}+\beta_{4} \text { SIZE }_{i t}+\beta_{5} \text { LEV }_{i t}+\beta_{6} \quad \text { CEO_DUALITY }_{i t}+
\end{aligned}
$$

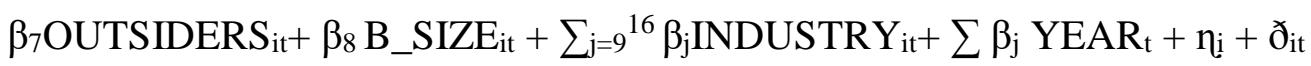


where the symbol ni represents the unobservable heterogeneity (firm-fixed and firmspecific effects). These unobservable effects of companies vary among individuals, but are constant over time and ðit represents the error term.

The estimator used for running the models is the generalised method of moments (GMM) (Arellano \& Bond, 1991). The efficiency and consistency of GMM in contrast with other procedures is greater because the unobservable heterogeneity $\left(\mathrm{n}_{\mathrm{i}}\right)$ is controlled. Additionally, the endogeneity and the estimation bias are also controlled by GMM procedure.

\section{Analysis of results}

\subsection{Descriptive statistics and correlations}

The descriptive statistics are provided in Table 5. As can be observed, the Q_TOBIN variable of firms in our sample, on average, is 0.73. CSR disclosure index (CSR_REPORT) can range between 0 and 1 and shows a figure of 0.25 or $25 \%$. According to this value, the disclosure of CSR items by the international firms in our sample is moderate (it varies between 0.1 and 0.5 ). This leads us to reflect about the need of improving the disclosure of CSR information by international firms because this figure is quite far of being a satisfactory value. Further, in $27.22 \%$ of firms in our sample, their CSR reports are assured by an external auditor (CSR_SUST_EXT_AUD) (external assurance provider). Firm size (SIZE) is, on average, 9.78 (log of total assets) and the leverage level (LEV) is, on average, $24.54 \%$. Additionally, in $30.14 \%$ of firms, the CEO of the firm also serves as the chairman of the board (CEODUALITY), 74.18\% of board members are outsiders and board size (B_SIZE), on average, is 10.44 members. The representation of every sector analysed in this research has been provided in the sample section.

\section{Insert Table 5}

For checking if there are multicollinearity concerns in this research, we have calculated the correlations among all pairs of variables. These correlations are shown in Table 6. As appreciated, all correlations coefficients are lower than 0.8 and, therefore, we can conclude that multicollinearity is not a problem in our research.

Insert Table 6

\subsection{Multivariate analysis}

The findings of the Model 1 are presented in Table 7. We aim to explore how CSR disclosure affects firm performance. The coefficient for this variable is positive, as expected, and statistically significant. This leads us to not reject the first hypothesis. This evidence shows that firms, which disclose more CSR information, are more likely to perform better. Our evidence from an international perspective is consistent with past research focused on 
national contexts (e.g., Pham \& Tran, 2020; Sardana, Gupta, Kumar, \& Terziovski 2020), which also reveals a positive association between CSR reporting and firm performance. By voluntarily disclosing CSR information firms pretend to publicize their efforts in this issue, to gain public approval (social license), to improve recruiting (talent attraction and retention), to invite other businesses to join the cause and to increase performance through a positive perception and a better reputation. Further, firms also report CSR information when operate in a sustainable and ethical way, addresses their social and environmental impacts and are interested in showing to stakeholders their social and environmental orientation toward society. Thus, firms, which disclose more CSR issues, will be more likely to perform better because this disclosure may allow firms to reach a higher legitimation, brand, reputation and recognition by stakeholders. CSR disclosure not only enhances firms' social and environmental values and reputation, but also enhances their performance. The control variables in Model 1 significativelly affecting firm performance are leverage, impacting on a positive way, and board size, consumer cyclical and healthcare sectors on a negative way. No more control variables show a significant effect on firm performance.

In Model 2, we examine the moderating role of an external assurance provider, who assures CSR reports, between CSR disclosure and firm performance. The interaction variable between CSR disclosure and CSR reports of firms assured by external assurance providers is represented by CSR_REPORT x CSR_SUST_EXT_AUD. As predicted, this variable exhibits a positive sign and is statistically significant, which leads us to suggest that CSR reports assured by external auditors (external assurance providers) moderates positively the relationship between CSR disclosure and firm performance. As far as we know, only the Akisik and Gal (2020)'s paper has focused on analysing whether assured integrated reports moderate the relationship between integrated disclosure and financial performance. However, in comparison to our research, the Akisik and Gal (2020)'s paper is based on a particular context, North America, and on integrated reporting, while our paper uses a wider set of countries and focuses on CSR disclosure. Consistent with our evidence, Akisik and Gal (2020) also find that the positive impact of integrated reports on financial performance is enhanced when these integrated reports are assured by accounting firms. Firms will be more likely to perform better when their CSR reports are assured by external auditors or external assurance providers. The purpose of external assurance goes beyond a statement from a third party that the contents of a report are true based on certain principles. It enhances confidence about the integrity of information and of underlying operational processes and improves the quality of an organization's decision-making process. Thus, CSR reports assured by external 
providers come from a process, which examines the completeness and veracity of CSR reports. CSR information assured by external auditors may safeguard that stakeholders' information needs are satisfied as well as this information is assured by independent providers (Maroun, 2020). This assurance gives credibility to the information provided in CSR reports and, therefore, decisions made in this information will be more reliable (Akisik and Gal, 2020). Additionally, this assurance can be also considered by firms as a legitimacy management tool in order to signal stakeholders and society their sensitiveness and orientation toward socials and environmental matters, and their interest in providing assured information on this topic. It is very important for firms to signal credibility of CSR disclosure when having to face with public scrutiny and with a crisis of confidence. This can benefit firms by resulting in an increase of firm performance. Then, the positive effect of CSR disclosure on firm performance may be greater if CSR information disclosed has been assured by external assurance providers. In this Model 2, only the control variable leverage (LEV) is positive and statistically significant. The remainder of control variables are insignificant.

\section{Concluding remarks}

Non-financial information such as CSR information is so relevant or more than financial information, particularly for stakeholders. Through CSR information, stakeholder are able to know how firms behave toward social and environmental issues and their impacts on society. Furthermore, CSR information may also benefit firms and their shareholders by enhancing firm performance because it is a tool for improving reputation and gaining legitimation. Thus, the purpose of this paper is to examine how CSR reporting affects firm performance. Furthermore, we also analyse whether CSR information assured by an external assurance provider moderates the association between CSR disclosure and firm performance.

The findings show that firms, which disclose more CSR information, are more likely to perform better. We use an international sample of firm made up by countries with differences in the culture, laws, customs and political system, among others. Although this, it seems that firms operating in these countries increase firm performance when disclosing CSR information. This evidence suggests that voluntary disclosure such as CSR disclosure is a mechanism for which firms can gain visibility, legitimation and reputations and, as a result, a higher firm performance is likely to result. We also find that when firms assure the CSR information disclosed by an external assurance provider, firms tend to perform better. The assurance of CSR disclosure positively moderates the positive effect of CSR disclosure on firm performance. 
Our evidence has several implications. First, our findings may be useful for firms, particularly shareholders, because CSR disclosure enhances firm performance. Even more, if an external assurance provider assures the disclosure of this CSR information, the increase in firm performance is higher. Then, shareholders may demand firms the disclosure of assured CSR information because it will result in a better firm performance. In the same regard, potential shareholders may also find relevant our evidence because it can guide them for investing on firms, which report CSR information assured by an external assurance provider, given its positive effect on firm performance. Second, policy-makers may recommend firms to report CSR information, specifically CSR information assured by an external assurance provider, because this recommendation may benefit several users such as: (1) stakeholders, who will receive a more credible CSR information for making decisions, (2) managers, who show a sensitiveness and commitment toward social and environmental issues and are more aligned with shareholder value maximisation, (3) firms, which need to improve their performance and (4) current and potential shareholders. Finally, our results may encourage other researchers to extend this topic. Firm performance is a relevant indicator for making decisions, and to shed new light into how other factors affect firm performance is necessary. This research provides evidence about the positive effect of the disclosure of CSR information assured by an external provider on firm performance, but the knowledge of other determinants influencing firm performance should merit the attention of the academy.

This paper has several caveats. First, although our sample covers many countries around the world, it is possible some relevant countries have been disregarded. We have considered all countries for which all necessary data for constructing the variables were available. Second, we have based on a market-oriented indicator for measuring firm performance, the $\mathrm{Q}$ of Tobin. This metric can be only used when firm are listing. Finally, we have controlled as many factors that potentially may affect firm performance as it has been possible. However, it is probably that other factors influencing firm performance have not been controlled.

From this research, a couple of future research lines can be suggested. First, the analysis of what effect other voluntary disclosures such as integrated reporting or sustainability disclosure would have on firm performance would shed new light into firms disclosure. Voluntary disclosures are not required by laws and, thus, those voluntary disclosures enhancing firm performance can be arbitrarily used by firms with this purpose. Secondly, we have excluded from our sample financial entities. We encourage firms to extend our research by focusing on an international sample of financial entities. 


\section{References}

Ackers, B. (2011). Corporate Social Responsibility: - an internal audit perspective. Internal Auditor Adviser - Part 1, Guilford Press, pp. 10-15.

Aerts, W., Cormier, D., \& Magnan, M. (2008). Corporate environmental disclosure, financial markets and the media: An international perspective. Ecological Economics, 64 (3), 643-659.

Akisik, O., \& Gal, G. (2020). Integrated reports, external assurance and financial performance: An empirical analysis on North American firms. Sustainability Accounting, Management and Policy Journal, 11 (2), 317-350.

Andersen, M. L., \& Dejoy, J. S. (2011). Corporate social and financial performance: the role of size, industry, risk, R\&D and advertising expenses as control variables. Business and Society Review, 116, 237 - 256.

Arellano, M., \& Bond, S. (1991). Some tests of specification for panel data: Monte Carlo evidence and an application to employment equations. Review of Economic Studies, 58, 277-297.

Barnett, M.L., \& Salomon, R.M. (2012). Does it pay to be really good? Addressing the shape of the relationship between social and financial performance. Strategic Management Journal, 33 (1), 1304-1320.

Boakye, D.J., Tingbani, I., Ahinful, G.S., Nsor-Ambala, R. (2021). The relationship between environmental management performance and financial performance of firms listed in the Alternative Investment Market (AIM) in the UK. Journal of Cleaner Production, 278.

Cahan, S. F., De Villiers, C., Jeter, D. C., Naiker, V., \& Van Staden, C. J. (2016). Are CSR disclosures value relevant?. Cross-country evidence. The European Accounting Review, 25(3), 579-611.

Carroll, A. B., \& Shabana, K. M. (2010). The business case for corporate social responsibility: A review of concepts, research and practice. International Journal of Management Review, 12(1), 85-105.

Casey, R.J., \& Grenier, J.H. (2015). Understating and contributing to the enigma of corporate social responsibility (CSR) assurance in the United States. Auditing: A Journal of Practice and Theory, 34 (1), 97-130.

Charlo, M., \& Moya, I. (2010). El comportamiento financiero de las empresas socialmente responsables. Investigaciones Europeas de Dirección de la Empresa, 16, 15-25.

Chen, H., \& Wang, X. (2011). Corporate social responsibility and corporate financial performance in China: an empirical research from Chinese firms. Corporate Governance: The International Journal of Business in Society, 11 (4), 361-370.

Choi, J., Kwak, Y., \& Choe, C. (2010). Corporate social responsibility and corporate financial performance: evidence from Korea. Australian Journal of Management, 35, 291 - 311.

Clarkson, M.B. (1995). A Stakeholder Framework for Analyzing and Evaluating Corporate Social Performance. The Academy of Management Review, 20 (1), 92-117.

Clarkson, P., Li, Y., Richardson, G., \& Tsang, A. (2019). Causes and consequences of voluntary assurance of CSR reports. International evidence involving Dow Jones Sustainability Index Inclusion and Firm Valuation. Accounting, Auditing \& Accountability Journal, 32 (8), 2451-2474.

Cormier, D., \& Magnan, M. (2007). The revisited contribution of environmental reporting to investors' valuation of a firm's earnings: An international perspective. Ecological Economics, 62, 613-626. 
Cormier, D., \& Magnan, M. (2015). The economic relevance of environmental disclosure and its impact on corporate legitimacy: an empirical investigation. Business Strategy and the Environment, 24 (6), 431-450.

De, S., \& Sen, P.K. (2002). Legal liabilities, audit accuracy and the market for audit services. Journal of Business Finance and Accounting, 29 (3/4), 353-411.

Deegan, C. (2006). Legitimacy theory, in Hoque, Z. (Ed.), Methodological Issues in Accounting Research: Theories and Methods, Spiramus Press, London, pp. 161-81.

Deegan, C., \& Blomquist, B. (2006). Stakeholders influence on corporate reporting: an exploration of the interaction between WWWF-Australia and Australian minerals industry. Accounting, Organization and Society, 31 (4-5), 343-372.

DiSegni, D.M., Huly, M., \& Akron, S. (2015). Corporate social responsibility, environmental leadership, and financial performance. Social Responsibility Journal, 11 (1), 131-148.

Dhaliwal, D., Radhakrishnan, S., Tsang, A., \& Yang, Y. (2012). Nonfinancial disclosure and analyst forecast accuracy: International evidence on corporate social responsibility disclosure. The Accounting Review, 87(3), 723-759.

Dhaliwal, D.S., Li, O.Z., Tsang, A., \& Yang, Y.G. (2011). Voluntary nonfinancial disclosure and the cost of equity capital: the initiation of corporate social responsibility reporting. The Accounting Review, 86 (1), 59-100.

Donaldson, T., \& Preston, L. E. (1995). The stakeholder theory of the corporation: concepts, evidence, and implications. Academy of Management Review, 20 (1), 65-91.

Freeman, R. (1984). Strategic Management: A Stakeholder Perspective. Pitman: Boston, MA.

Friedman, M. (1970). The social responsibility of business is to increase its profits. New York Times Magazine, 13, 122-126.

Fuhrmann, S., Otto, C., Looks, E., \& Guenther, T.W. (2017). The content of assurance statements for sustainability reports and information asymmetry. Accounting and Business Research, 47 (4), 369-400.

García-Ramos, R., Díaz-Díaz, B., García-Olalla, M. (2017). Independent directors, large shareholders and firm performance: the generational stage of family businesses and the socioemotional wealth approach. Review of Managerial Science, 11,119-156.

García-Sánchez, I.-M., \& Noguera-Gámez, L. (2017). Integrated information and the cost of capital. International Business Review, 26 (5), 959-975.

Gray, R., Kouhy, R., \& Lavers, S. (1995). Corporate social and environmental reporting: A review of the literature and longitudinal study of UK disclosure. Accounting, Auditing \& Accountability Journal, 8(2), 47-77.

Hahn, R., \& Lülfs, R. (2014). Legitimizing negative aspects in GRI-oriented sustainability reporting: A qualitative analysis of corporate disclosure strategies. Journal of Business Ethics, 123 (3), 401-420.

Husted, B.W. (2005). Risk management, real options, and corporate social responsibility. Journal of Business Ethics, 60 (2), 175-183.

Institute of Internal Auditors (IIA). (2012), International Professional Practices Framework. Altamonte Springs, FL.

Jones, T. (1995). Instrumental stakeholder theory: a synthesis of ethics and economics. Academy of Management Review, 20 (2), 404-437.

Kreitner, R. (2001). Management. Houghton Mifflin Company, New York, NY.

Kurschner, D. (1996). Five ways ethical business creates fatter profits. Business Ethics: The Magazine of Corporate Responsibility, 10, 20-23.

Lin, W.L., Ho, J.A., Lee, C., Ng, S.I. (2020). Impact of positive and negative corporate social responsibility on automotive firms' financial performance: A market-based asset perspective. Corporate Social Responsibility and the Environment Management, 27, 1761-1773. 
Lindgreen, A., Swaen, V., \& Johnston, W.J. (2009). Corporate social responsibility: an empirical investigation of US organizations. Journal of Business Ethics, 85 (2), 303323.

Martínez-Ferrero, J., \& Frias-Aceituno, J. (2015) Relationship between sustainable development and financial performance: international empirical research. Business Strategy and the Environment, 24(1), 20-39

Michelon, G., Patten, D., \& Romi, A.M. (2019). Creating legitimacy for sustainability assurance practices: evidence from sustainability restatement. European Accounting Review, 28 (2), 395-422.

Nekhili, M., Nagati, H., Chtioui, T., \& Rebolledo, C. (2017). Corporate social responsibility disclosure and market value: Family versus nonfamily firms. Journal of Business Research, 77, 41-52.

Park, J., \& Brorson, T. (2005). Experiences of and view on third-party assurance of corporate environmental and sustainability reports. Journal of Cleaner Production, 13, 1095-1106.

Peloza, J. (2006). Using corporate social responsibility as insurance for financial performance. California Management Review, 48 (2), 52-72.

Perego, P., \& Kolk, A. (2012). Multinationals' accountability on sustainability: the evolution of thirdparty assurance on sustainability reports. Journal of Business Ethics, 110 (2), 173-190.

Peters, G.F., \& Romi, A.M. (2015). The association between sustainability governance characteristics and the assurance of corporate sustainability reports. Auditing: A Journal of Practice and Theory, 34 (1), 163-198.

Pham, H.S.T., Tran, H.T. (2020). CSR disclosure and firm performance: The mediating role of corporate reputation and moderating role of CEO integrity. Journal of Business Research, 120, 127-136.

Pucheta-Martínez, M.C., Gallego-Álvarez, I. (2020). Do board characteristics drive firm performance? An international perspective. Review of Managerial Science, 14, 12511297.

Reverte, C. (2016). Corporate social responsibility disclosure and market valuation: evidence from Spanish listed firms. Review of Managerial Science, 10, 411-435.

Richardson, A. J., \& Welker, M. (2001). Social disclosure, financial disclosure and the cost of equity capital. Accounting, Organizations and Society, 26 (7), 597-616.

Saleh, M., Zulkifli, N., \& Muhamad, R. (2008). An empirical examination of the relationship between corporate social responsibility disclosure and financial performance in an emerging market. 16th Annual Conference on Pacific Basin Finance Economics Accounting Management Conference, Brisbane, Queensland.

Sardana, D., Gupta, N., Kumar, V., Terziovski, M. (2020). CSR 'sustainability' practices and firm performance in an emerging economy. Journal of Cleaner Production, 258.

Siueia, T.T., Wang, J., Deladem, T.G. (2019). Corporate Social Responsibility and financial performance: A comparative study in the Sub-Saharan Africa banking sector. Journal of Cleaner Production, 226, 658-668.

Soh, D.S.B., \& Martinov-Bennie, N. (2015). Internal auditors' perceptions of their role in environmental, social and governance assurance and consulting. Managerial Auditing Journal, 30 (1), 80-111.

Tilling, M.V. (2004). Some thoughts on legitimacy theory in social and environmental accounting. Social and Environmental Accountability Journal, 24(2), 3-7. 
Table 1

Number of observations by country

\begin{tabular}{lccc}
\hline Country & Observations & Percentage & Cum. \\
\hline Australia & 779 & 7.9 & 7.9 \\
Austria & 34 & 0.3 & 8.2 \\
Belgium & 88 & 0.9 & 9.1 \\
Canada & 1,105 & 11.2 & 20.3 \\
Denmark & 108 & 1.1 & 21.4 \\
Finland & 133 & 1.3 & 22.8 \\
Germany & 349 & 3.5 & 26.3 \\
Ireland & 169 & 1.7 & 28.0 \\
Japan & 1,491 & 15.1 & 43.2 \\
Netherlands & 212 & 2.1 & 45.3 \\
New Zealand & 51 & 0.5 & 45.8 \\
Norway & 59 & 0.6 & 46.4 \\
Sweden & 214 & 2.2 & 48.6 \\
Switzerland & 375 & 3.8 & 52.4 \\
United Kingdom & 1173 & 11.9 & 64.3 \\
United States & 3521 & 35.7 & 100.0 \\
\hline Total & 9,861 & 100.0 & \\
\hline
\end{tabular}

Table 2

Number of observations by activity sector

\begin{tabular}{lccc}
\hline \multicolumn{1}{c}{ TRBC economic sector name } & Number of observations & Percentage & Cum. \\
\hline Basic Materials & 1,357 & 13.8 & 13.8 \\
Consumer cyclical. & 1,960 & 19.9 & 33.6 \\
Consumer Non-Cyclical & 987 & 10.0 & 43.6 \\
Energy & 855 & 8.7 & 52.3 \\
Healthcare & 876 & 8.9 & 61.2 \\
Industrial & 2,144 & 21.7 & 82.9 \\
Technology & 863 & 8.8 & 91.7 \\
Telecommunications Services & 324 & 3.3 & 95.0 \\
Utilities & 495 & 5.0 & 100.0 \\
\hline Total & 9,861 & 100.0 & 13.8 \\
\hline
\end{tabular}


Table 3

Corporate social responsibility disclosure

Environmental

\begin{tabular}{|c|c|c|c|c|c|c|}
\hline Resource use & Emissions & Innovation & Workforce & $\begin{array}{l}\text { Human } \\
\text { rights }\end{array}$ & Community & $\begin{array}{l}\text { Product } \\
\text { responsibility }\end{array}$ \\
\hline $\begin{array}{l}\text { Resource reduction } \\
\text { policy }\end{array}$ & $\begin{array}{l}\text { Policy } \\
\text { emissions }\end{array}$ & $\begin{array}{l}\text { Environmental } \\
\text { products }\end{array}$ & $\begin{array}{l}\text { Health and } \\
\text { safety policy } \\
\text { Policy }\end{array}$ & $\begin{array}{l}\text { Human rights } \\
\text { policy }\end{array}$ & $\begin{array}{l}\text { Employee } \\
\text { engagement } \\
\text { volunt work }\end{array}$ & $\begin{array}{l}\text { Policy customer } \\
\text { health and safety }\end{array}$ \\
\hline $\begin{array}{l}\text { Policy water } \\
\text { efficiency }\end{array}$ & $\begin{array}{l}\text { Targets } \\
\text { emissions }\end{array}$ & $\begin{array}{l}\text { Eco-design } \\
\text { products }\end{array}$ & $\begin{array}{l}\text { employee } \\
\text { health and } \\
\text { safety }\end{array}$ & $\begin{array}{l}\text { Policy } \\
\text { freedom of } \\
\text { association }\end{array}$ & $\begin{array}{l}\text { Corporate } \\
\text { responsibility } \\
\text { awards } \\
\text { Product sales }\end{array}$ & $\begin{array}{l}\text { Policy data } \\
\text { privacy }\end{array}$ \\
\hline $\begin{array}{l}\text { Policy energy } \\
\text { efficiency }\end{array}$ & $\begin{array}{l}\text { Biodiversity } \\
\text { impact } \\
\text { reduction }\end{array}$ & Noise reduction & $\begin{array}{l}\text { Policy supply } \\
\text { chain health } \\
\text { and safety } \\
\text { Training and }\end{array}$ & $\begin{array}{l}\text { Policy child } \\
\text { labor }\end{array}$ & $\begin{array}{l}\text { at discount to } \\
\text { emerging } \\
\text { markets } \\
\text { Diseases of }\end{array}$ & $\begin{array}{l}\text { Policy } \\
\text { responsible } \\
\text { marketing }\end{array}$ \\
\hline $\begin{array}{l}\text { Policy sustainable } \\
\text { packaging }\end{array}$ & $\begin{array}{l}\text { Emissions } \\
\text { trading } \\
\text { Climate change }\end{array}$ & Hybrid vehicles & $\begin{array}{l}\text { development } \\
\text { policy }\end{array}$ & $\begin{array}{l}\text { Policy forced } \\
\text { labor }\end{array}$ & $\begin{array}{l}\text { the developing } \\
\text { world } \\
\text { Bribery }\end{array}$ & Policy fair trade \\
\hline $\begin{array}{l}\text { Policy environment } \\
\text { supply chain }\end{array}$ & $\begin{array}{l}\text { commercial } \\
\text { risks } \\
\text { opportunities } \\
\text { Nox and Sox }\end{array}$ & $\begin{array}{l}\text { Environmental } \\
\text { assets under } \\
\text { MGT }\end{array}$ & $\begin{array}{l}\text { Policy skills } \\
\text { training }\end{array}$ & $\begin{array}{l}\text { Policy human } \\
\text { rights } \\
\text { Fundamental }\end{array}$ & $\begin{array}{l}\text { corruption and } \\
\text { fraud } \\
\text { controversies } \\
\text { Crisis }\end{array}$ & $\begin{array}{l}\text { Product } \\
\text { responsibility } \\
\text { monitor }\end{array}$ \\
\hline $\begin{array}{l}\text { Resource reduction } \\
\text { targets }\end{array}$ & $\begin{array}{l}\text { emissions } \\
\text { reduction } \\
\text { Voc or }\end{array}$ & $\begin{array}{l}\text { Equator } \\
\text { principles } \\
\text { Equator }\end{array}$ & $\begin{array}{l}\text { Policy career } \\
\text { development }\end{array}$ & $\begin{array}{l}\text { human rights } \\
\text { ILO UN }\end{array}$ & $\begin{array}{l}\text { management } \\
\text { systems }\end{array}$ & $\begin{array}{l}\text { Quality mgt } \\
\text { systems }\end{array}$ \\
\hline $\begin{array}{l}\text { Environment } \\
\text { management team } \\
\text { Environment } \\
\text { management } \\
\text { training }\end{array}$ & $\begin{array}{l}\text { particulate } \\
\text { matter } \\
\text { emissions } \\
\text { Voc emissions } \\
\text { reduction } \\
\text { Particulate } \\
\text { matter }\end{array}$ & $\begin{array}{l}\text { principles or } \\
\text { environmental } \\
\text { projects } \\
\text { Environmental } \\
\text { project } \\
\text { financing }\end{array}$ & $\begin{array}{l}\text { Policy } \\
\text { diversity and } \\
\text { opportunity } \\
\text { Employees } \\
\text { health and } \\
\text { safety team }\end{array}$ & $\begin{array}{l}\text { Human rights } \\
\text { contractor } \\
\text { Ethical trading } \\
\text { initiative ETI } \\
\text { Human rights }\end{array}$ & $\begin{array}{l}\text { Anti } \\
\text { competition } \\
\text { controversies }\end{array}$ & $\begin{array}{l}\text { ISO } 9000 \\
\text { Six sigma and } \\
\text { quality mgt } \\
\text { systems }\end{array}$ \\
\hline $\begin{array}{l}\text { Environmental } \\
\text { materials sourcing }\end{array}$ & $\begin{array}{l}\text { emission } \\
\text { reduction }\end{array}$ & Nuclear & $\begin{array}{l}\text { Health and } \\
\text { safety training } \\
\text { Supply chain }\end{array}$ & $\begin{array}{l}\text { breaches } \\
\text { contractor }\end{array}$ & & $\begin{array}{l}\text { Product access } \\
\text { low price }\end{array}$ \\
\hline $\begin{array}{l}\text { Toxic chemicals } \\
\text { reduction }\end{array}$ & $\begin{array}{l}\text { Waste } \\
\text { reduction total }\end{array}$ & Labeled wood & $\begin{array}{l}\text { health and } \\
\text { safety training } \\
\text { Employees }\end{array}$ & & & $\begin{array}{l}\text { Healthy food or } \\
\text { products }\end{array}$ \\
\hline $\begin{array}{l}\text { Renewable energy } \\
\text { use }\end{array}$ & $\begin{array}{l}\text { e-Waste } \\
\text { reduction } \\
\text { Environmental }\end{array}$ & $\begin{array}{l}\text { Organic } \\
\text { products } \\
\text { initiatives }\end{array}$ & $\begin{array}{l}\text { health and } \\
\text { safety OHSAS } \\
18001\end{array}$ & & & $\begin{array}{l}\text { Embryonic stem } \\
\text { cell research }\end{array}$ \\
\hline Green buildings & $\begin{array}{l}\text { restoration } \\
\text { initiatives } \\
\text { Staff }\end{array}$ & $\begin{array}{l}\text { Product impact } \\
\text { minimization }\end{array}$ & $\begin{array}{l}\text { Flexible } \\
\text { working hours }\end{array}$ & & & $\begin{array}{l}\text { Retailing } \\
\text { responsibility }\end{array}$ \\
\hline $\begin{array}{l}\text { Environmental } \\
\text { supply chain } \\
\text { management }\end{array}$ & $\begin{array}{l}\text { transportation } \\
\text { impact } \\
\text { reduction }\end{array}$ & $\begin{array}{l}\text { Take-back and } \\
\text { recycling } \\
\text { initiatives }\end{array}$ & $\begin{array}{l}\text { Day care } \\
\text { services }\end{array}$ & & & alcohol \\
\hline $\begin{array}{l}\text { Environmental } \\
\text { supply chain } \\
\text { monitoring } \\
\text { Env supply chain }\end{array}$ & $\begin{array}{l}\text { Environmental } \\
\text { expenditures } \\
\text { investment }\end{array}$ & $\begin{array}{l}\text { Product } \\
\text { environmental } \\
\text { responsible use }\end{array}$ & $\begin{array}{l}\text { Employee } \\
\text { fatalities }\end{array}$ & & & gambling \\
\hline $\begin{array}{l}\text { partnership } \\
\text { termination } \\
\text { Land environmental } \\
\text { impact reduction }\end{array}$ & & $\begin{array}{l}\text { GMO products } \\
\text { Agrochemical } \\
\text { products }\end{array}$ & $\begin{array}{l}\text { HIV-AIDS } \\
\text { program } \\
\text { Internal } \\
\text { promotion }\end{array}$ & & & $\begin{array}{l}\text { tobacco } \\
\text { armaments }\end{array}$ \\
\hline Environmental & & Agrochemical & Management & & & Obesity risk \\
\hline
\end{tabular}


Animal testing condition

Antipersonal

cosmetics

controversies

landmines

Animal testing

Consumer

reduction

complaints

Renewable

clean energy

Customer

products controversies

Water Responsible

technologies

marketing

Sustainable

controversies 
Table 4

Variables description

\begin{tabular}{|c|c|}
\hline Variables & Description \\
\hline Q_TOBIN & $\begin{array}{l}\text { The market capitalization of common stock }+ \text { book value liabilities divided by the book } \\
\text { value of total assets }\end{array}$ \\
\hline CSR_REPORT & $\begin{array}{l}\text { The ratio between the aggregation of } 123 \text { items concerning social and environmental } \\
\text { issues and the total items }(123)\end{array}$ \\
\hline CSR_SUST_EXT_AUD & $\begin{array}{l}\text { It is a dummy variable, which takes the value } 1 \text { if the company's CSR report is assured } \\
\text { by an external auditor (external assurance provider) and } 0 \text {, otherwise }\end{array}$ \\
\hline SIZE & The log of total assets \\
\hline LEV & Debt over total assets \\
\hline CEODUALITY & $\begin{array}{l}\text { Dummy variable that takes the value } 1 \text { if the same person serves simultaneously as CEO } \\
\text { and President of the board and } 0 \text {, otherwise }\end{array}$ \\
\hline OUTSIDERS & $\begin{array}{l}\text { The proportion of external directors on boards }=\text { Total number of external directors on } \\
\text { boards/ Total number of directors on boards }\end{array}$ \\
\hline B_SIZE & The total number of directors on boards \\
\hline BASIC MATERIALS & Dummy variable: $1=$ Basic Materials; $0=$ Otherwise \\
\hline CONSUMER CYCLICAL & Dummy variable: $1=$ Consumer Cyclical; $0=$ Otherwise \\
\hline $\begin{array}{l}\text { CONSUMER NON- } \\
\text { CYCLICAL }\end{array}$ & Dummy variable: $1=$ Consumer Non-Cyclical; $0=$ Otherwise \\
\hline ENERGY & Dummy variable: $1=$ Energy; $0=$ Otherwise \\
\hline HEALTHCARE & Dummy variable: $1=$ Healthcare; $0=$ Otherwise \\
\hline INDUSTRIALS & Dummy variable: $1=$ Industrial; $0=$ Otherwise \\
\hline TECHNOLOGY & Dummy variable: $1=$ Technology; $0=$ Otherwise \\
\hline $\begin{array}{l}\text { TELECOMMUNICATION } \\
\text { SERVICES }\end{array}$ & Dummy variable: $1=$ Telecommunication Services; $0=$ Otherwise \\
\hline UTILITIES & Dummy variable: $1=$ Utilities; $0=$ Otherwise \\
\hline
\end{tabular}


Table 5

Descriptive analysis

\begin{tabular}{lccc}
\hline \multicolumn{1}{c}{ Variable } & Obs & Mean & Std. Dev. \\
\hline Q_TOBIN & 9,861 & 0.735 & 0.377 \\
CSR_REPORT & 9,861 & 25.000 & 15.850 \\
CSR_SUST_EXT_AUD & 9,861 & 27.218 & 44.510 \\
SIZE & 9,861 & 9.785 & 0.619 \\
LEV & 9,861 & 24.537 & 16.211 \\
CEODUALITY & 9,861 & 30.139 & 45.889 \\
OUTSIDERS & 9,861 & 74.178 & 25.823 \\
B_SIZE & 9,861 & 10.440 & 3.246 \\
BASIC MATERIALS & 9,861 & 13.800 & 34.451 \\
CONSUMER CYCLICAL & 9,861 & 19.900 & 39.908 \\
CONSUMER NON-CYCLICAL & 9,861 & 10.000 & 30.013 \\
ENERGY & 9,861 & 8.700 & 28.141 \\
HEALTHCARE & 9,861 & 8.900 & 28.451 \\
INDUSTRIALS & 9,861 & 21.700 & 41.251 \\
TECHNOLOGY & 9,861 & 8.800 & 28.260 \\
TELECOMMUNICATION SERVICES & 9,861 & 3.300 & 17.827 \\
UTILITIES & 9,861 & 5.000 & 21.836 \\
\hline
\end{tabular}

Mean and standard deviation. Q_TOBIN is the market capitalization of common stock+ book value liabilities divided by the book value of total assets; CSR_REPORT is the ratio between the aggregation of 123 items concerning social and environmental issues and the total items (123); CSR_SUST_EXT_AUD is a dummy variable, which takes the value 1 if the company's CSR report is assured by an external auditor (external assurance provider) and 0, otherwise; SIZE is the log of total assets; LEV is the debt over total assets; CEODUALITY is a dummy variable that takes the value 1 if the same person serves simultaneously as CEO and President of the board and 0, otherwise; OUTSIDERS is measured as the proportion of outside directors on boards; B_SIZE is the number of directors on board; Basic Materials if the company operates in Basic Materials sector and 0, otherwise; Consumer Cyclical if the company operates in Consumer Cyclical sector and 0, otherwise; Consumer Non-Cyclical if the company operates in Consumer Non-Cyclical sector and 0, otherwise; Energy if the company operates in Energy sector and 0, otherwise; Healthcare if the company operates in Healthcare sector and 0, otherwise; Industrials if the company operates in Industrials sector and 0, otherwise; Technology if the company operates in Technology sector and 0, otherwise; Telecommunication Services if the company operates in Telecommunication Services sector and 0, otherwise; Utilities if the company operates in Utilities sector and 0 , otherwise. 
Table 6

Correlation matrix

\begin{tabular}{|c|c|c|c|c|c|c|c|c|c|c|c|c|c|c|c|c|}
\hline & (1) & (2) & (3) & (4) & $(5)$ & (6) & (7) & (8) & (9) & (10) & (11) & (12) & (13) & (14) & (15) & (16) \\
\hline$\overline{\text { Q_TOBIN (1) }}$ & 1 & & & & & & & & & & & & & & & \\
\hline CSR_REPORT(2) & 0.001 & 1 & & & & & & & & & & & & & & \\
\hline CSR_SUST_EXT_AUD (3) & $0.027 * * *$ & $0.570^{* * *}$ & 1 & & & & & & & & & & & & & \\
\hline SIZE (4) & $-0.021 * *$ & $0.569 * * *$ & $0.390^{* * *}$ & 1 & & & & & & & & & & & & \\
\hline LEV(5) & $0.578 * * *$ & $0.066^{* * * *}$ & $0.058^{* * * *}$ & $0.197 * * *$ & 1 & & & & & & & & & & & \\
\hline CEODUALITY(6) & $-0.108^{* * *}$ & $-0.030^{* * * *}$ & $-0.128 * * *$ & $0.144 * * *$ & 0.009 & 1 & & & & & & & & & & \\
\hline OUTSIDERS(7) & $-0.072 * * *$ & $0.079 * * *$ & $-0.072 * * *$ & $0.145^{* * * *}$ & $0.051^{* * * *}$ & $0.080^{* * * *}$ & 1 & & & & & & & & & \\
\hline B_SIZE(8) & $-0.029 * * *$ & $0.356^{* * * *}$ & $0.205^{* * * *}$ & $0.569^{* * * *}$ & $0.113^{* * * *}$ & $0.092 * * *$ & $0.135^{* * * *}$ & 1 & & & & & & & & \\
\hline BASIC MATERIALS (9) & $-0.051 * * *$ & $0.045 * * *$ & $0.098 * * *$ & $-0.068 * * *$ & $-0.030 * * *$ & $-0.100 * * *$ & 0.011 & $-0.071 * * *$ & 1 & & & & & & & \\
\hline CONSUMER CYCLICAL (10) & $0.017 *$ & $-0.075 * * *$ & $-0.071 * * *$ & $-0.071 * * *$ & -0.013 & $0.017 *$ & $-0.112 * * *$ & -0.009 & $-0.199 * * *$ & 1 & & & & & & \\
\hline CONSUMER NON-CYCLICAL (11) & $0.048^{* * * *}$ & $0.097 * * *$ & $0.029 * * *$ & $0.047 * * *$ & $0.075^{* * *}$ & -0.001 & $0.029 * * *$ & $0.081 * * *$ & $-0.133 * * *$ & $-0.166 * * *$ & 1 & & & & & \\
\hline ENERGY (12) & $-0.147 * * *$ & $-0.098 * * *$ & $-0.024 * *$ & $0.038 * * *$ & $-0.068 * * *$ & $0.045^{* * * *}$ & $0.055 * * *$ & $-0.032^{* * * *}$ & $-0.123 * * *$ & $-0.153 * * *$ & $-0.103 * * * *$ & 1 & & & & \\
\hline HEALTHCARE (13) & $-0.131 * * *$ & $-0.044 * * *$ & $-0.057 * * *$ & $-0.050^{* * * *}$ & $-0.045^{* * * *}$ & $0.021 * *$ & $0.086 * * *$ & $-0.056 * * *$ & $-0.125 * * *$ & $-0.156^{* * * *}$ & $-0.104 * * *$ & $-0.096 * * *$ & 1 & & & \\
\hline INDUSTRIALS (14) & $0.171 * * *$ & $0.030 * * *$ & $0.012^{* * * *}$ & 0.002 & $0.039^{* * * *}$ & -0.000 & $-0.068^{* * * *}$ & $0.041^{* * * *}$ & $-0.211^{* * * *}$ & $-0.263^{* * * *}$ & $-0.176 * * * *$ & $-0.162^{* * * * *}$ & $-0.164 * * *$ & 1 & & \\
\hline $\begin{array}{l}\text { TECHNOLOGY (15) } \\
\text { TELECOMMUNICATION }\end{array}$ & $-0.138^{* * *}$ & 0.004 & $-0.039 * * *$ & $-0.052 * * *$ & $-0.212^{* * * *}$ & 0.012 & $-0.027 * * *$ & $-0.071 * * *$ & $-0.123 * * *$ & $-0.154 * * * *$ & $-0.103^{* * * *}$ & -0.095 **** & $-0.096 * * *$ & $-0.163^{* * * *}$ & 1 & \\
\hline SERVICES (16) & $0.080 * * *$ & 0.010 & $0.053^{* * * *}$ & $0.101 * * *$ & $0.132 * * *$ & $-0.028 * *$ & $0.057 * * *$ & $0.056^{* * * *}$ & $-0.073 * * *$ & $-0.091 * * *$ & $-0.061^{* * * * *}$ & $-0.057 * * *$ & $-0.057 * * *$ & $-0.097 * * *$ & $-0.057 * * *$ & 1 \\
\hline UTILITIES (17) & $0.132 * * *$ & $0.044 * * *$ & $0.023 * *$ & $0.170^{* * * *}$ & $0.207 * * * *$ & $0.049 * * *$ & $0.081^{* * *}$ & $0.102 * * *$ & $-0.091 * * *$ & $-0.114^{* * * * *}$ & $-0.076^{* * * * *}$ & $-0.071 * * * *$ & $-0.071^{* * * *}$ & $-0.121 * * *$ & $-0.071 * * *$ & $-0.042 * * *$ \\
\hline
\end{tabular}

Q_TOBIN is the market capitalization of common stock+ book value liabilities divided by the book value of total assets; CSR_REPORT is the ratio between the aggregation of 123 items concerning social and environmental issues and the total items (123); CSR_SUST_EXT_AUD is a dummy variable, which takes the value 1 if the company's CSR report is assured by an external auditor (external assurance provider) and 0, otherwise; SIZE is the log of total assets; LEV is the debt over total assets; CEODUALITY is a dummy variable that takes the value 1 if the same person serves simultaneously as CEO and President of the board and 0 , otherwise; OUTSIDERS is measured as the proportion of outside directors on boards; B_SIZE is the number of directors on board; Basic Materials if the company operates in Basic Materials sector and 0, otherwise; Consumer Cyclical if the company operates in Consumer Cyclical sector and 0, otherwise; Consumer Non-Cyclical if the company operates in Consumer Non-Cyclical sector and 0, otherwise; Energy if the company operates in Energy sector and 0, otherwise; Healthcare if the company operates in Healthcare sector and 0, otherwise; Industrials if the company operates in Industrials sector and 0, otherwise; Technology if the company operates in Technology sector and 0 , otherwise; Telecommunication Services if the company operates in Telecommunication Services sector and 0 , otherwise; Utilities if the company operates in Utilities sector and 0 , otherwise. *p-value $<0.1 * *$ p-value $<0.05 * * *$ p-value $<0.01$ 
Table 7

Multivariate analysis results of the Generalised Method of Moments

\begin{tabular}{lcc}
\multicolumn{2}{c}{ Multivariate analysis results of the Generalised Method of Moments } \\
\hline & $\begin{array}{c}\text { MODEL } \\
\text { Coef. }\end{array}$ & $\begin{array}{c}\text { MODEL } 2 \\
\text { Coef. }\end{array}$ \\
\hline Q_TOBIN(t-1) & $0.385^{* * *}$ & $0.382^{* * *}$ \\
CSR_REPORT & $0.565^{*}$ & -0.210 \\
CSR_SUST_EXT_AUD & & -0.324 \\
SIZE & 0.295 & -0.154 \\
LEV & $0.016^{* * *}$ & $0.006^{* *}$ \\
CEODUALITY & -0.187 & -0.153 \\
OUTSIDERS & -0.001 & 0.001 \\
B_SIZE & $-0.220^{* * *}$ & 0.003 \\
BASIC MATERIALS & -0.862 & 0.480 \\
CONSUMER CYCLICAL & $-1.493 * *$ & 0.548 \\
CONSUMER NON-CYCLICAL & -1.189 & 0.77 \\
HEALTHCARE & $-1.869 *$ & -0.103 \\
INDUSTRIALS & -1.014 & 0.851 \\
TECHNOLOGY & -1.260 & -0.057 \\
TELECOMMUNICATION SERVICES & -0.041 & 0.504 \\
UTILITIES & -0.289 & 0.533 \\
CSR_REPORT x CSR_SUST_EXT_AUD & & $0.794 * *$ \\
\hline Year effects & Yes & Yes \\
Wald $\boldsymbol{\chi}^{2}$ test & $181.18^{* * *}$ & $563.62^{* * *}$ \\
Arellano--Bond test AR(1) $(\mathbf{z}, \mathbf{p}>|\mathbf{z}|)$ & $-3.14(0.002)$ & $-2.64(0.008)$ \\
Arellano--Bond test AR(2) $(\mathbf{z}, \mathbf{p}>|\mathbf{z}|)$ & $-1.63(0.102)$ & $-1.19(0.233)$ \\
Hansen test $\left(\mathbf{c h i}-\mathbf{s q u a r e , ~} \mathbf{p}>\mathbf{c h i}{ }^{2} \mid\right)$ & $11.52(0.568)$ & $32.86(0.135)$ \\
\hline
\end{tabular}

Q_TOBIN is the market capitalization of common stock+ book value liabilities divided by the book value of total assets; CSR_REPORT is the ratio between the aggregation of 123 items concerning social and environmental issues and the total items (123); CSR_SUST_EXT_AUD is a dummy variable, which takes the value 1 if the company's CSR report is assured by an external auditor (external assurance provider) and 0, otherwise; SIZE is the log of total assets; LEV is the debt over total assets; CEODUALITY is a dummy variable that takes the value 1 if the same person serves simultaneously as CEO and President of the board and 0 , otherwise; OUTSIDERS is measured as the proportion of outside directors on boards; B_SIZE is the number of directors on board; Basic Materials if the company operates in Basic Materials sector and 0, otherwise; Consumer Cyclical if the company operates in Consumer Cyclical sector and 0, otherwise; Consumer Non-Cyclical if the company operates in Consumer Non-Cyclical sector and 0, otherwise; Energy if the company operates in Energy sector and 0, otherwise; Healthcare if the company operates in Healthcare sector and 0, otherwise; Industrials if the company operates in Industrials sector and 0, otherwise; Technology if the company operates in Technology sector and 0, otherwise; Telecommunication Services if the company operates in Telecommunication Services sector and 0 , otherwise; Utilities if the company operates in Utilities sector and 0 , otherwise. *p-value $<0.1 * *$ p-value $<0.05 * * *$ p-value $<0.01$ 